\title{
Estimation of Critical Temperature, Critical Pressure, and Normal Boiling Point of Alkanes and Alkenes
}

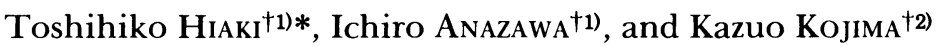 \\ †1) Dept. of Industrial Chemistry, College of Industrial Technology, Nihon University, \\ 1-2-1 Izumi-cho, Narashino-shi, Chiba 275 \\ †2) Dept. of Industrial Chemistry, College of Science and Technology, Nihon University, \\ 1-8 Surugadai, Kanda, Chiyoda-ku, Tokyo 101
}

(Received July 10, 1989)

\begin{abstract}
A simple and accurate method was developed, based exclusively on molecular weight and structure, to estimate the critical temperature, critical pressure, and normal boiling point of alkanes and alkenes including their isomers. With the proposed method, these properties can be calculated for $20 n$-alkanes of carbon from 1 to 20, 44 branched alkanes of carbon from 4 to 10, sixteen 1 -alkenes of carbon from 2 to 18 , and 20 alkenes, other than 1 -alkene of carbon from 4 to 8 . A comparison of the results obtained by this method with those by conventional estimation methods is also presented.
\end{abstract}

\section{Introduction}

Critical temperature and pressure are essential physical properties for the development and design of chemical processes. Thus, various methods $\left.\left.\left.{ }^{1)} \sim 4\right), 6,8\right), 9,15\right)$ for estimating these properties have been proposed. In order to estimate these properties of hydrocarbons, including branched alkanes, it is necessary to identify and distinguish their isomers. Thus, many of the conventional methods have introduced normal boiling point as one of the variables.

This paper proposes a method for estimating critical temperatures and pressures and normal boiling points of alkanes and alkenes as functional forms consistent with their molecular weight and structure. A comparison of the estimated values obtained by the present method with those by conventional methods is also presented.

\section{Functional Form of Estimation Equation}

In this estimation method, critical temperature and pressure are calculated by use only the molecular weight, $M$, of $n$-alkanes and l-alkenes. The general functional form is given by Eq. (1).

$$
\begin{aligned}
Q_{n}= & A+B / M^{0.8}+C \cdot(\ln M) / M^{0.8} \\
& +D \cdot(\ln M)^{1.5} / M^{0.8}+E \cdot(\ln M)^{2} / M^{0.8}
\end{aligned}
$$

where $Q_{n}$ represents either the critical temperature or critical pressure of $n$-alkane or 1-alkene whose

\footnotetext{
* To whom correspondence should be addressed.
}

molecular weight is $M$, and $A$ to $E$ are the constants which will be shown below.

For branched alkanes ( $i$-alkanes) and alkenes (except 1-alkenes and cis-alkenes), a general form of Eq. (2) is employed.

$$
\begin{aligned}
Q_{i}= & Q_{n}+\left[F+G \cdot\left(p_{n}-p_{i}\right)\right. \\
& \left.+H\left\{0.8 \cdot\left(p_{n}-p_{i}\right)+\left(w_{n}-w_{i}\right)\right\} / M^{2}\right]
\end{aligned}
$$

where $Q_{i}$ represents either the critical temperature or pressure of $i$-alkane or $i$-alkene (except l-alkene and cis-alkene), and $Q_{n}$ is the calculated value of the corresponding $n$-alkane or 1 -alkene given by Eq. (1).

In addition, the Platt number, $p^{11)}$, and the Wiener number, $w^{16)}$, are introduced to distinguish between the isomers. Those numbers are calculated based on the structural formula of the molecule. In the original reports, both numbers have been defined for alkanes. Therefore, these numbers are extended to alkenes in this study (see Appendix).

The values of critical temperature and pressure and normal boiling point used in this work are obtained from a data base of Reid, Prausnitz, and Poling. ${ }^{13)}$

\section{Estimation of Critical Temperature}

\section{1 n-Alkanes}

Values of $A$ to $E$ in Eq. (1) were determined by fitting the critical temperatures of $20 n$-alkanes of carbon from 1 to 20 . The critical temperature of $n$-alkane, $T_{c, n}$, can be expressed by Eq. (3). 


$$
\begin{aligned}
T_{c, n}= & 1289.558-26646.223 / M^{0.8} \\
& +32373.522 \cdot(\ln M) / M^{0.8} \\
& -17414.799 \cdot(\ln M)^{1.5} / M^{0.8} \\
& +934.002 \cdot(\ln M)^{2} / M^{0.8}
\end{aligned}
$$

The average and maximum absolute deviations between the values calculated by Eq. (3) and those observed are shown in Table 1. This table shows also the deviations between the values calculated by using some of the conventional estimation methods and those observed. The results from Eq. (3) are found to be most accurate.

\subsection{Branched Alkanes ( $i$-alkanes)}

On the basis of the observed values of critical temperature for 44 branched alkanes of carbon from 4 to 10 , constants, $F$ to $H$, in Eq. (2) were determined. The estimation equation for critical temperature of $i$-alkane, $T_{c, i}$, is given by Eq. (4).

$$
\begin{aligned}
T_{c, i}= & T_{c, n}+\left[-3.9376-7.6628 \cdot\left(p_{n}-p_{i}\right)\right. \\
& -16253.6123\left\{0.8 \cdot\left(p_{n}-p_{i}\right)+\left(w_{n}\right.\right. \\
& \left.\left.\left.-w_{n}\right)\right\} / M^{2}\right]
\end{aligned}
$$

where $T_{c, n}$ is the critical temperature of $n$-alkane calculated using Eq. (3). Deviations of the values estimated by Eq. (4) from those observed are shown in Table 1, which includes the deviations from the values estimated by the conventional methods. Although the present equation includes only the molecular weight as a variable, it is shown to reproduce the observed values, within the allowable limits of deviation, comparable with those obtained by the Ambrose method that includes two variables: the normal boiling point and the Platt number.

\subsection{Alkenes}

There are three types of estimation equation for alkenes, i.e., for the 1 -alkenes, cis-alkenes, and other alkenes.
For 1-alkene, values of $A$ to $E$ in Eq. (1) were determined on the basis of the observed values of sixteen 1-alkenes of carbon from 2 to 18 (except $\left.\mathrm{C}_{16}\right)$. The estimation equation thus obtained is given by Eq. (5).

$$
\begin{aligned}
T_{c, 1 \text {-alkene }}= & 1192.700-62597.783 / M^{0.8} \\
& +88924.776 \cdot(\ln M) / M^{0.8} \\
& -56795.098 \cdot(\ln M)^{1.5} / M^{0.8} \\
& +8885.519 \cdot(\ln M)^{2 /} M^{0.8}
\end{aligned}
$$

For alkenes, except 1-alkenes and cis-alkenes, the estimation equation of critical temperature, derived by fitting the observed values, is given by Eq. (6).

$$
\begin{aligned}
T_{c, i \text {-alkene }}= & T_{c, 1 i \text {-alkene }}+[4.1776-1.4034 \\
& \cdot\left(p_{n}-p_{i}\right)-13830.0233\{0.8 \\
& \left.\left.\cdot\left(p_{n}-p_{i}\right)+\left(w_{n}-w_{i}\right)\right\} / M^{2}\right]
\end{aligned}
$$

The estimation equation for cis-alkenes was derived by fitting the observed values for 4 cis-alkenes.

$$
T_{c, c i s}=T_{c, \text { i-alkene }}+16.78-0.22 \cdot M
$$

\begin{tabular}{|c|c|c|c|c|c|c|c|c|c|c|}
\hline \multirow{3}{*}{ Author } & \multirow{3}{*}{$\begin{array}{l}\text { Applying } \\
\text { range of } \\
\text { estimation }\end{array}$} & \multicolumn{4}{|c|}{ Deviation $(\mathrm{K})$} & \multirow{3}{*}{$\begin{array}{l}\text { Applying } \\
\text { range of } \\
\text { estimation }\end{array}$} & \multicolumn{4}{|c|}{ Deviation $(\mathrm{K})$} \\
\hline & & \multicolumn{2}{|c|}{$n$-Alkene } & \multicolumn{2}{|c|}{ Branched alkane } & & \multicolumn{2}{|c|}{ 1-Alkene } & \multicolumn{2}{|c|}{ Except 1-alkene } \\
\hline & & AAD & MAD & AAD & MAD & & AAD & MAD & AAD & MAD \\
\hline This work & $\mathrm{C}_{1}-\mathrm{C}_{20}$ & 0.7 & 2.1 & 1.4 & 4.2 & $\mathrm{C}_{2}-\mathrm{C}_{18}$ & 0.7 & 2.1 & 3.5 & 10.7 \\
\hline $\begin{array}{l}\text { Jalowka and } \\
\text { Daubert (1986) }\end{array}$ & $\mathrm{C}_{2}-\mathrm{C}_{13}$ & 2.0 & 6.6 & 1.4 & 6.9 & $\mathrm{C}_{2}-\mathrm{C}_{13}$ & 1.8 & 4.6 & 6.7 & 14.5 \\
\hline $\begin{array}{l}\text { Klincewicz and } \\
\text { Reid (1984) }\end{array}$ & $\mathrm{C}_{2}-\mathrm{C}_{10}$ & 4.4 & 9.4 & 3.0 & 9.6 & $\mathrm{C}_{2}-\mathrm{C}_{10}$ & 4.5 & 13.0 & 4.5 & 14.6 \\
\hline $\begin{array}{l}\text { Lin and Chao } \\
(1984)\end{array}$ & $\mathrm{C}_{1}-\mathrm{C}_{20}$ & 1.2 & 3.9 & 9.0 & 42.5 & $\mathrm{C}_{2}-\mathrm{C}_{18}$ & 1.8 & 10.1 & 10.6 & 20.8 \\
\hline Fedors (1982) & $\mathrm{C}_{2}-\mathrm{C}_{20}$ & 1.6 & 9.1 & 9.3 & 41.8 & $\mathrm{C}_{2}-\mathrm{C}_{18}$ & 2.4 & 13.6 & 5.9 & 15.0 \\
\hline Ambrose (1974) & $C_{1}-C_{20}$ & 0.9 & 4.2 & 0.7 & 3.0 & $\mathrm{C}_{2}-\mathrm{C}_{18}$ & 1.9 & 9.0 & 5.6 & 12.0 \\
\hline $\begin{array}{l}\text { Stiel and } \\
\text { Thodos (1962) }\end{array}$ & $\mathrm{C}_{3}-\mathrm{C}_{10}$ & 2.6 & 9.9 & 2.3 & 7.5 & & & & & \\
\hline $\begin{array}{l}\text { Forman and } \\
\text { Thodos (1958) }\end{array}$ & $\mathrm{C}_{2}-\mathrm{C}_{15}$ & 5.3 & 14.0 & 11.5 & 81.2 & $\mathrm{C}_{2}-\mathrm{C}_{15}$ & 3.9 & 10.0 & 5.6 & 14.4 \\
\hline Lydesen (1955) & $\mathrm{C}_{2}-\mathrm{C}_{20}$ & 3.6 & 8.7 & 3.0 & 12.2 & $\mathrm{C}_{2}-\mathrm{C}_{18}$ & 2.9 & 6.1 & 7.2 & 17.9 \\
\hline
\end{tabular}

Deviations of the values estimated by Eqs. (5) to (7) from the observed values are shown in Table 1, which includes also the deviations resulted from using previous methods. For the critical temperature of 1-alkene, the present method using Eq. (5) gives an average absolute deviation of $0.7 \mathrm{~K}$ and a maximum absolute deviation of $2.1 \mathrm{~K}$.

For alkenes, other than 1-alkene, the method using Eqs. (6) and (7) yields an average absolute deviation of $3.5 \mathrm{~K}$ and a maximum absolute deviation of $10.7 \mathrm{~K}$.

Table 1 Comparison of Estimation Results of Critical Temperature between This Study and Previous Methods for Alkanes and Alkenes

AAD (average absolute deviation): $\left(\sum^{N}\left|T_{c, \text { cal }}-T_{c, o b s}\right|\right) / N, N$ : number of data, MAD: maximum absolute deviation 


\section{Estimation of Critical Praesure}

\section{$4.1 \quad n$-Alkanes}

Values of $A$ to $E$ in Eq. (1) for estimating the critical pressure of $n$-alkane were determined by fitting the observed data. The equation for estimating the critical pressure of $n$-alkane, $P_{c, n}$, is given by Eq. (8).

$$
\begin{aligned}
P_{c, n}= & -2.325-508.355 / M^{0.8} \\
& +736.225 \cdot(\ln M) / M^{0.8} \\
& -481.175 \cdot(\ln M)^{1.5} / M^{0.8} \\
& +97.839 \cdot(\ln M)^{2} / M^{0.8}
\end{aligned}
$$

Deviations of the values estimated by Eq. (8) from the observed values are shown in Table 2, which includes also the deviations observed by the previous methods. The results estimated by Eq. (8) are more accurate than any of the conventionally estimated ones.

\subsection{Branched Alkanes ( $i$-alkanes)}

The equation for estimating the critical pressure of $i$-alkanes, $P_{c, i}$, is given by Eq. (9).

$$
\begin{aligned}
P_{c, i}= & P_{c, n}+\left[-0.0100-0.0636 \cdot\left(p_{n}-p_{i}\right)\right. \\
& \left.+28.8562\left\{0.8 \cdot\left(p_{n}-p_{i}\right)+\left(w_{n}-w_{i}\right)\right\} / M^{2}\right]
\end{aligned}
$$

The resulting deviations by Eq. (9) are shown in Table 2.

\subsection{Alkenes}

The equation for estimating the critical pressure of 1 -alkenes was similarly derived as it was for $n$-alkanes, using only their molecular weights, as in Eq. (1). The critical pressure of 1-alkene, $P_{c, 1 \text {-alkene, }}$ is given by Eq. (10).

$$
\begin{aligned}
P_{c, 1 \text {-alkene }}= & -3.471-899.812 / M^{0.8} \\
& +1326.702 \cdot(\ln M) / M^{0.8} \\
& -882.730 \cdot(\ln M)^{1.5} / M^{0.8} \\
& +177.499 \cdot(\ln M)^{2} / M^{0.8}
\end{aligned}
$$

For alkenes, except l-alkene and cis-alkene, the equation derived from their observed critical pressures is developed into Eq. (11).

$$
\begin{aligned}
P_{c, i \text {-alkene }}= & P_{c, 1 \text {-alkene }}+\left[0.0028-0.0310 \cdot\left(p_{n}-p_{i}\right)\right. \\
& -55.6782\left\{0.8 \cdot\left(p_{n}-p_{i}\right)\right. \\
& \left.\left.+\left(w_{n}-w_{i}\right)\right\} / M^{2}\right]
\end{aligned}
$$

For cis-alkenes, their critical pressure can be expressed by Eq. (12)

$$
P_{c, c i s}=P_{c, i \text {-alkene }}+0.41-0.0048 \cdot M
$$

Table 2 shows the deviations of the values estimated by Eqs. (10) to (12) and those observed, including the results estimated by the conventional methods. The average absolute deviation for 1-alkenes is found to be $0.016 \mathrm{MPa}$ and the maximum absolute deviation $0.036 \mathrm{MPa}$. For alkenes, except 1 -alkenes, the present method gives an absolute deviation of $0.048 \mathrm{MPa}$ and a maximum absolute deviation of $0.150 \mathrm{MPa}$.

\section{Equation for Estimating Normal Boiling Points of Alkanes and Alkenes}

\begin{tabular}{|c|c|c|c|c|c|c|c|c|c|c|}
\hline \multirow{3}{*}{ Author } & \multirow{3}{*}{$\begin{array}{l}\text { Applying } \\
\text { range of } \\
\text { estimation }\end{array}$} & \multicolumn{4}{|c|}{ Deviation $(\mathbf{K})$} & \multirow{3}{*}{$\begin{array}{l}\text { Applying } \\
\text { range of } \\
\text { estimation }\end{array}$} & \multicolumn{4}{|c|}{ Deviation $(\mathrm{K})$} \\
\hline & & \multicolumn{2}{|c|}{$n$-Alkane } & \multicolumn{2}{|c|}{ Branched alkane } & & \multicolumn{2}{|c|}{ l-Alkene } & \multicolumn{2}{|c|}{ Except 1-alkene } \\
\hline & & AAD & MAD & AAD & MAD & & AAD & MAD & AAD & MAD \\
\hline This work & $\mathrm{C}_{1}-\mathrm{C}_{20}$ & 0.017 & 0.045 & 0.027 & 0.066 & $\mathrm{C}_{2}-\mathrm{C}_{18}$ & 0.016 & 0.036 & 0.048 & 0.150 \\
\hline $\begin{array}{l}\text { Jalowka and } \\
\text { Daubert (1986) }\end{array}$ & $\mathrm{C}_{2}-\mathrm{C}_{20}$ & 0.044 & 0.110 & 0.035 & 0.133 & $\mathrm{C}_{2}-\mathrm{C}_{18}$ & 0.049 & 0.143 & 0.076 & 0.353 \\
\hline $\begin{array}{l}\text { Lin and Chao } \\
(1984)\end{array}$ & $\mathrm{C}_{2}-\mathrm{C}_{20}$ & 0.023 & 0.116 & 0.176 & 0.404 & $\mathrm{C}_{2}-\mathrm{C}_{18}$ & 0.084 & 0.238 & 0.181 & 0.443 \\
\hline Ambrose (1974) & $\mathrm{C}_{1}-\mathrm{C}_{20}$ & 0.057 & 0.426 & 0.015 & 0.046 & $\mathrm{C}_{2}-\mathrm{C}_{18}$ & 0.075 & 0.283 & 0.099 & 0.230 \\
\hline $\begin{array}{l}\text { Steil and } \\
\text { Thodos (1962) }\end{array}$ & $\mathrm{C}_{3}-\mathrm{C}_{10}$ & 0.043 & 0.133 & 0.054 & 0.223 & & & & & \\
\hline $\begin{array}{l}\text { Forman and } \\
\text { Thodos (1958) }\end{array}$ & $\mathrm{C}_{2}-\mathrm{C}_{15}$ & 0.031 & 0.063 & 0.129 & 0.534 & $\mathrm{C}_{2}-\mathrm{C}_{15}$ & 0.032 & 0.073 & 0.088 & 0.418 \\
\hline Lydesen (1955) & $\mathrm{C}_{2}-\mathrm{C}_{20}$ & 0.038 & 0.146 & 0.115 & 0.377 & $\mathrm{C}_{2}-\mathrm{C}_{18}$ & 0.081 & 0.312 & 0.096 & 0.184 \\
\hline
\end{tabular}

Estimation of the normal boiling point, $T_{b}$, was also attempted in a manner similar to that used for critical temperature and pressure. The equation for estimating the normal boiling point of an $n$ alkane, $T_{b, n}$, is given by Eq. (13).

$$
\begin{aligned}
T_{b, n}= & 1563.217+25843.400 / M^{0.8} \\
& -76703.381 \cdot(\ln M) / M^{0.8} \\
& +69616.048 \cdot(\ln M)^{1.5} / M^{0.8} \\
& -19241.408 \cdot(\ln M)^{2} / M^{0.8}
\end{aligned}
$$

For branched alkanes, the value of $T_{b}$ is expressed by Eq. (14).

$$
\begin{aligned}
T_{b, i}= & T_{b, n}+\left[-0.5205-5.5056 \cdot\left(p_{n}-p_{i}\right)\right. \\
& \left.-19163.8056 \cdot\left(w_{n}-w_{i}\right) / M^{2}\right]
\end{aligned}
$$

Table 2 Comparison of Estimation Results of Critical Pressure between This Study and Previous Methods for Alkanes and Alkenes

AAD (average absolute deviation): $\left(\sum^{N}\left|P_{c, c a l}-P_{c, \text { obs }}\right|\right) / N, N$ : number of data, MAD: maximum absolute deviation 
Table 3 Comparison of Estimation Result of Normal Boiling Point between This Study and Previous Methods for Alkanes and Alkenes

\begin{tabular}{|c|c|c|c|c|c|c|c|c|c|c|}
\hline \multirow{3}{*}{ Author } & \multirow{3}{*}{$\begin{array}{l}\text { Applying } \\
\text { range of } \\
\text { estimation }\end{array}$} & \multicolumn{4}{|c|}{ Deviation (K) } & \multirow{3}{*}{$\begin{array}{l}\text { Applying } \\
\text { range of } \\
\text { estimation }\end{array}$} & \multicolumn{4}{|c|}{ Deviation $(\mathrm{K})$} \\
\hline & & \multicolumn{2}{|c|}{$n$-Alkane } & \multicolumn{2}{|c|}{ Branched alkane } & & \multicolumn{2}{|c|}{ 1-Alkene } & \multicolumn{2}{|c|}{ Except 1-alkene } \\
\hline & & AAD & MAD & $\mathrm{AAD}$ & MAD & & AAD & MAD & AAD & MAD \\
\hline This work & $\mathrm{C}_{1}-\mathrm{C}_{20}$ & 0.3 & 0.9 & 0.6 & 2.5 & $\mathrm{C}_{2}-\mathrm{C}_{18}$ & 0.2 & 0.4 & 4.0 & 11.3 \\
\hline $\begin{array}{l}\text { Lai, Chen and } \\
\text { Maddox (1987) }\end{array}$ & $\mathrm{C}_{2}-\mathrm{C}_{20}$ & 6.5 & 11.4 & 5.2 & 13.1 & $\mathrm{C}_{2}-\mathrm{C}_{18}$ & 5.3 & 18.1 & 6.4 & 27.9 \\
\hline $\begin{array}{l}\text { Purarelli } \\
\quad(1976)\end{array}$ & $\mathrm{C}_{1}-\mathrm{C}_{20}$ & 7.2 & 35.1 & 7.5 & 31.2 & $\mathrm{C}_{2}-\mathrm{C}_{18}$ & 1.6 & 17.6 & 6.9 & 22.4 \\
\hline $\begin{array}{l}\text { Steil and } \\
\text { Thodos (1962) }\end{array}$ & $\mathrm{C}_{3}-\mathrm{C}_{10}$ & 0.1 & 0.2 & 0.7 & 3.1 & & & & & \\
\hline $\begin{array}{l}\text { Ogata and } \\
\text { Tsuchida (1957) }\end{array}$ & $\mathrm{C}_{1}-\mathrm{C}_{7}$ & 8.5 & 41.8 & & & & & & & \\
\hline $\begin{array}{l}\text { Somayajulu and } \\
\text { Palit (1957) }\end{array}$ & $\mathrm{C}_{1}-\mathrm{C}_{20}$ & 1.8 & 3.9 & & & & & & & \\
\hline Kinney (1940) & $\mathrm{C}_{1}-\mathrm{C}_{20}$ & 1.9 & 6.8 & 2.7 & 16.2 & $\mathrm{C}_{2}-\mathrm{C}_{18}$ & 1.7 & 3.1 & 2.8 & 12.0 \\
\hline
\end{tabular}

AAD (average absolute deviation): $\left(\sum^{N}\left|T_{b . \text { cal }}-T_{b, o b s}\right|\right) / N, N$ : number of data, MAD: maximum absolute deviation

The results of average absolute deviation from the observed values are listed in Table 3. Deviations estimated by the conventional methods are also given in this table. The results from Eqs. (13) and (14) are most accurate.

The equation for estimating the normal boiling point of alkenes is developed in a manner similar to that for estimating the critical temperature and critical pressure. The equation for l-alkene,

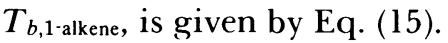

$$
\begin{aligned}
T_{b, 1 \text {-alkene }}= & 1499.731-13791.427 / M^{0.8} \\
& -15160.900 \cdot(\ln M) / M^{0.8} \\
& +27455.613 \cdot(\ln M)^{1.5} / M^{0.8} \\
& -10972.085 \cdot(\ln M)^{2} / M^{0.8}
\end{aligned}
$$

For $i$-alkenes, except 1 -alkenes and cis-alkenes, Eq. (16) is used.

$$
\begin{aligned}
T_{b, \text {-alkene }}= & T_{b, 1 \text {-alkene }}+[1.1267-0.9285 \\
& \cdot\left(p_{n}-p_{i}\right)-13624.6156 \\
& \left.\cdot\left(w_{n}-w_{i}\right) / M^{2}\right]
\end{aligned}
$$

Estimation for cis-alkenes is given by Eq. (17).

$$
T_{b, c i s}=T_{b, i \text {-alkene }}+15.94-0.22 \cdot M
$$

Deviations from the observed values are shown in Table 3. The table also includes the deviations calculated by the conventional estimation methods $\left.\left.{ }^{5)}, 7\right), 10\right)$, 12), 14), 15).

\section{Appendix}

\section{Calculation of the Platt Number and the Wiener Number}

The Platt number, $p$, is indicated as the number of pairs of carbon atoms three bond apart (i.e. C-C-C-C). For example, for compound, $n$ hexane $\left(\mathrm{C}_{6}\right)$, the Platt number $p=3$. For 2,3- dimethyl butane $\left(\mathrm{C}_{6}\right), p=4$.

$$
\begin{aligned}
& n \text {-Hexane } \\
& \mathrm{CH}_{3}-\mathrm{CH}_{2}-\mathrm{CH}_{2}-\mathrm{CH}_{2}-\mathrm{CH}_{2}-\mathrm{CH}_{3} \\
& \text { 2-3-4-5 } \\
& \begin{array}{lllllll}
\mathrm{l} & 2 & 3 & 4 & 5 & 6 & 3-4-5-6
\end{array} \\
& p=3
\end{aligned}
$$

2,3-Dimethyl butane

$$
\begin{aligned}
& 24 \\
& \mathrm{CH}_{3} \mathrm{CH}_{3} \\
& \text { I } 1 \\
& \mathrm{CH}_{3}-\mathrm{CH}-\mathrm{CH}-\mathrm{CH}_{3} \\
& \text { 2-3-5-6 } \\
& p=4
\end{aligned}
$$

In this study the Platt number is extended to alkenes. For alkenes, the double bond is defined as two carbon-carbon bonds, and the Platt number $p$ is counted. For example, for compound l-hexene, $p=4$, or for 2,3-dimethyl-1-butene, $p=6$.

\section{1-Hexene}

2,3-Dimethyl-1-butene<smiles>C=C(C)C(C)C</smiles>

The Wiener number, $w$, is calculated by multiplying the number of carbon atoms on one 
side of each carbon-carbon bond by the number of carbons on the other side of the bond and adding all the contributions from each carbon-carbon bond in the structural formula. For $n$-hexane, $w=35$, or for 2,3-dimethyl butane, $w=29$; the procedure is as follows.

$n$-Hexane

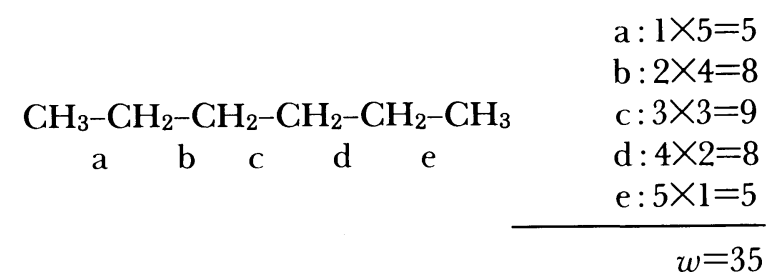

2,3-Dimethyl butane

\begin{tabular}{cr}
$\mathrm{CH}_{3} \mathrm{CH}_{3}$ & $\mathrm{a}: \mathrm{l} \times 5=5$ \\
b| d| & $\mathrm{b}: \mathrm{l} \times 5=5$ \\
$\mathrm{CH}_{3}-\mathrm{CH}-\mathrm{CH}-\mathrm{CH}_{3}$ & $\mathrm{c}: 3 \times 3=9$ \\
$\mathrm{a}$ c e & $\mathrm{d}: \mathrm{l} \times 5=5$ \\
& $\mathrm{e}: 5 \times 1=5$ \\
\hline$w=29$
\end{tabular}

On the other hand, the Wiener number of alkenes is employed in a manner similar to the Platt number. Therefore, for 1-hexene, $w=40$, or for 2,3-dimethyl-1-butene, $w=34$.

\section{1-Hexene}

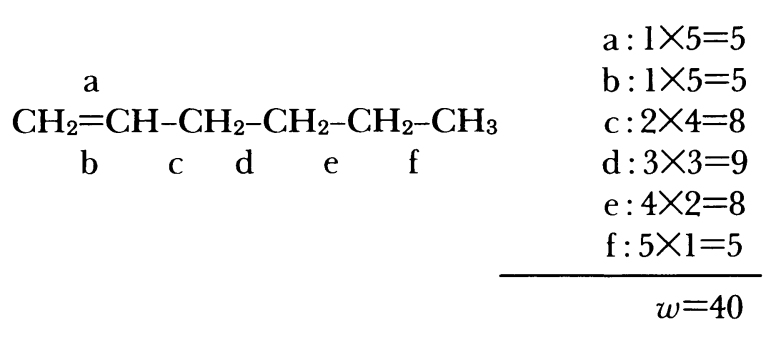

\section{2,3-Dimethyl-1-butene}

$$
\begin{array}{cr}
\mathrm{CH}_{3} \mathrm{CH}_{3} & \mathrm{a}: 1 \times 5=5 \\
\text { a } \mathrm{lc} & \mathrm{b}: 1 \times 5=5 \\
\mathrm{CH}_{2}=\mathrm{C}-\mathrm{CH}-\mathrm{CH}_{3} & \mathrm{c}: 1 \times 5=5 \\
\mathrm{~b} \text { d f } & \mathrm{d}: 3 \times 3=9 \\
& \mathrm{e}: 1 \times 5=5 \\
& \mathrm{f}: 5 \times 1=5 \\
\hline & w=34
\end{array}
$$

\section{Nomenclatures}

$A, B, C, D, E$ : constants in Eq. (1)

$F, G, H$ : constants in Eq. (2)

$M$ : molecular weight

$p_{i}:$ the Platt number of $i$-alkane or alkene (except 1 -alkene)

$p_{n}:$ the Platt number of $n$-alkane or l-alkene

$P_{c}:$ critical pressure

$T_{b}$ : normal boiling point

$T_{c}$ : critical temperature

$w_{i}:$ the Wiener number of $i$-alkane or alkene (except l-alkene)

$w_{n}$ : the Wiener number of $n$-alkane or l-alkene

\section{References}

1) Ambrose, D., Broderick, B. E., Townsend, R., J. Appl. Chem. Biotechnol., 24, 359 (1974).

2) Fedors, R. F., Chem. Eng. Comm., 16, 149 (1982).

3) Forman, J. C., Thodos, G., AIChE J., 4, 356 (1958).

4) Jalowka, J. W., Daubert, T. E., Ind. Eng. Chem. Process Des. Dev., 25, 139 (1986).

5) Kinney, C. R., Ind. Eng. Chem., 32, 559 (1940).

6) Klincewicz, K. M., Reid, R. C., AIChE J., 30, 137 (1984).

7) Lai, W. Y., Chen, D. H., Maddox, R. N., Ind. Eng. Chem. Res., 26, 1072 (1987).

8) Lin, H. M., Chao, K. C., AIChE J., 30, 981 (1984).

9) Lydesen, A. L., Univ. of Wisconsin, Eng. Exp. Sta. Rep., Madison, 1955.

10) Ogata, Y., Tsuchida, M., Ind. Eng. Chem., 49, 415 (1957).

11) Platt, J. R., J. Phys. Chem., 56, 328 (1952).

12) Purarelli, C., Chem. Eng., 30, 127 (1976).

13) Reid, R. C., Prausnitz, J. M., Poling, B. E., "The Properties of Gases and Liquids, fourth edition", McGraw-Hill, New York (1986).

14) Somayajulu, G. R., Palit, S. R., J. Chem. Soc., 1957, 2540.

15) Stiel, L. I., Thodos, G., AIChE J., 8, 527 (1962).

16) Wiener, H., J. Am. Chem. Soc., 69, 17 (1947). 


\title{
アルカンおよびアルケンの臨界温度, 臨界圧力ならびに標準沸点の推算
}

\author{
日秋 俊彦 ${ }^{11)}$, 穴澤 一郎 ${ }^{\dagger 1)}$, 小島 和夫 ${ }^{\dagger 2}$ \\ 1) 日本大学生産工学工業化学科, 275 千葉県習志野市泉町 1-2-1 \\ 2) 日本大学理工学部工業化学科, 101 東京都千代田区神田駿河台 1-8
}

臨界温度, 臨界圧力は化学プロセスの解析や設計に必須の物 性である。したがって, 臨界温度, 臨界圧力については各種の 推算法(1) 4),6),8),9,15) が提案されているが，i-アルカンを含め広 く炭化水素の推算を行うためには異性体を区別する必要があ り,このため標準沸点が多くの場合用いられている。本研究は 物質の分子量と化学構造のみに基づいてアルカンおよびアルケ ンの臨界温度, 臨界圧力および標準沸点の推算法を示し, 既往 の方法による推算結果と比較検討したものである。

まずn-アルカン, 1-アルケンの臨界温度, 臨界圧力および 標準沸点の基本推算式として分子量 $M$ のみを含む Eq. (1) を 採用した。また $i$-アルカンならびに1-アルケン以外のアルケ ン（cis-アルケンを除く）の基本推算式は, 化学構造式に基づ いて計算する Platt 数 $p$ および Wiener 数 $w$ を含む Eq. (2) を 採用し，is-アルケンに対しては分子量のみを含む式を用い た。本研究で用いたアルカンおよびアルケンの臨界温度, 臨界 压力ならびに標準沸点の実測值はすべて Reid, Prausnitz およ

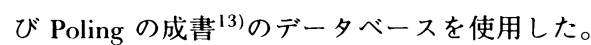

20 種の n-アルカン $\left(\mathrm{C}_{1} \sim \mathrm{C}_{20}\right)$ および 44 種の $i-$ アルカン $\left(\mathrm{C}_{4} \sim \mathrm{C}_{10}\right)$ の臨界温度デー夕を用いて Eq. (1) および Eq.

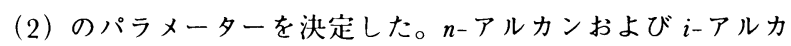
ンの臨界温度の推算式を Eqs. (3), (4) に示す。推算値と実測 值との絶対算術平均偏差はそれぞれ $0.7 \mathrm{~K}, 1.4 \mathrm{~K}$, 最大偏差
は $2.1 \mathrm{~K}, 4.2 \mathrm{~K}$ であった。また 16 種の1ーアルケン $\left(\mathrm{C}_{2}\right.$ 〜 $\mathrm{C}_{18}, \mathrm{C}_{16}$ を除く）执よび 20 種の 1-アルケン以外のアルケン $\left(\mathrm{C}_{4} \sim \mathrm{C}_{8}\right)$ の臨界温度データに基づいて Eq. (1) および Eq. (2) のパラメーターを決定した。1-アルケンおよび1-アルケン以 外のアルケンの臨界温度の推算式を Eqs. (5)〜 (7) に示す。推 算値と実測値との絶対算術平均偏差はそれぞれ $0.7 \mathrm{~K}, 3.5$ $\mathrm{K}$ ，また最大偏差 $2.1 \mathrm{~K}, 10.7 \mathrm{~K}$ であった。同様にして Eqs. （1），(2）を用いて臨界圧力の推算を行った。n-アルカンおよ び $i$ アアルカンの臨界圧力の推算式を Eqs. (8), (9)に, 1-アル ケンおよび 1-アルケン以外のアルケンの推算式を Eqs. (10)

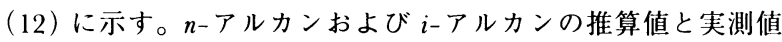
との絶対算術平均偏差はそれぞれ $0.017 \mathrm{MPa}, 0.027 \mathrm{MPa}$, 最大偏差は 0.045 MPa, 0.066 MPa であった。1-アルケンお よび 1-アルケン以外のアルケンは絶対算術平均偏差はそれぞ れ $0.016 \mathrm{MPa}, 0.048 \mathrm{MPa}$ であった。また標準沸点の推算も 同様にして行った。 $n$-アルカンおよび $i$-アルカンの標準沸点 の推算式 Eqs. (13)，(14)，1-アルケンおよび1-アルケン以外 のアルケンの推算式を Eqs. (15)〜（17）に示す。 $n$-アルカンお よび $i$-アルカンの推算値と実測值との絶対算術平均偏差が 0.3 $\mathrm{K}, 0.6 \mathrm{~K}$, 最大偏差は $0.9 \mathrm{~K}, 2.5 \mathrm{~K}, 1$ 1アルケンおよび 1 アルケン以外のアルケンでは絶対算術平均偏差はそれぞれ 0.2 $\mathrm{K}, 4.0 \mathrm{~K}$ ，最大偏差が $0.4 \mathrm{~K}, 11.3 \mathrm{~K}$ であった。

\section{Keywords}

Estimation equation, Critical temperature, Critical pressure, Normal boiling point, Alkane, Alkene 